\title{
Museum Performativity and the Agency of Sacred Objects
}

Performatividad museal y la voluntad de los objetos sagrados

\section{Matías Cornejo González}

\section{(2) OpenEdition \\ Journals}

Electronic version

URL: http://journals.openedition.org/iss/1413

DOI: $10.4000 /$ iss. 1413

ISSN: 2306-4161

Publisher

ICOM - International Council of Museums

\section{Printed version}

Date of publication: 12 October 2019

Number of pages: $73-87$

ISBN: 978-92-9012-467-2

ISSN: 2309-1290

Electronic reference

Matías Cornejo González, "Museum Performativity and the Agency of Sacred Objects », ICOFOM Study Series [Online], 47(1-2) | 2019, Online since 12 October 2019, connection on 24 October 2019. URL : http://journals.openedition.org/iss/1413 ; DOI : 10.4000/iss. 1413 


\section{Museum Performativity and the Agency of Sacred Objects}

Matías Cornejo González

National Museum of Fine Arts - Santiago, Chile

We treat our artwork as people because many of them represent our ancestors who for us are real persons

Sid Mead

ABSTRACT

Based on a critical revision of the Easter Island statue exhibit Hoa Hakananai'a at the British Museum, this paper discusses how indigenous sacred objects have been traditionally interpreted and displayed by Western universal museums. However, considering the influence of colonialism in the way these objects tend to be presented, it explores the potential of performativity in museums and its relevance for understanding the concept of agency in native ancestors' representations. Therefore, it is argued that, through the integration of divergent

I. Hirini 'Sidney' Moko Mead (quoted in Hakiwai, 2004, p. I6I), International Māori leader and Polynesian art scholar, co-curator of Te Māori exhibition (Carbonell, 20I2). 
non-Western ways of interpreting their collections, museums could promote participation, diversity and constructive connections with source communities and visitors alike, as contemporary museology has urged. Relating to similar cases, it also pays attention to the process of repatriation that Rapa Nui people have formally begun, with the support of the Chilean state as the constitution responsible for that territory. What is the role of museums in contemporary societies?

Key words: Museology, Native people, Cultural Rights, Repatriation, Religious objects, Museum ethics.

\section{RESUMEN}

\section{Performatividad museal y la voluntad de los objetos sagrados}

Basado en una revisión crítica de la exhibición del moái Hoa Hakananai'a en el Museo Británico, este artículo discute cómo los objetos religiosos pertenecientes a culturas originarias han sido tradicionalmente interpretados y exhibidos en museos universales de Occidente. Sin embargo, considerando la influencia del Colonialismo en las formas en que estos objetos tienden a ser presentados, se explora el potencial de la performatividad en museos y su relevancia para comprender la condición de persona en las representaciones religiosas de pueblos nativos. En consecuencia, se argumenta que a través de la integración de formas divergentes, no occidentales, en la interpretación de sus colecciones, los museos podrían promover la participación, diversidad y vínculos constructivos tanto con las comunidades de origen como con sus visitantes, como la museología contemporánea ha propuesto. No obstante, al comparar este caso con otros similares, también se presta atención al proceso de repatriación que el pueblo Rapa Nui ha comenzado formalmente con la ayuda del estado chileno como responsable constitucional de este territorio. ¿Cuál es el rol de los museos en las sociedades contemporáneas?

Palabras claves: Museología, Pueblos originarios, Derechos culturales, Repatriación, Objetos religiosos, Ética museal.

\section{*}

\section{Moai Hoa Hakananai'a, a lost or stolen friend?}

Conceived as modern institutions, museums have had the role of embodying Enlightenment thoughts, based on reason and scientific knowledge, in opposition to religious or spiritual understanding of the world. In this sense, one 
might argue that the musealization of native religious objects has been a core topic in museological discussion, as it represents one of the most important differences between the West and indigenous communities. Similarly, the encyclopaedic museum approach is also related to the development of human science and research of the unknown "others", with specific interest in so-called primitive cultures, whose sacred objects and human remains were usually held in private collections during "the cabinet of curiosities" period that can be traced back to the ${ }_{1} 6^{\text {th }}$ century (Hall, 1997; Delbourgo, 2007; Curtis, 20I2; Knell, 20I2). Thus, upon a historical review (Peiser, 2005; Tcherkézoff, 2008; Young, 2012; Seelenfreund \& Mardones, 2018), we could argue that, while some native cultures such as the Rapa Nui were "discovered" or allegedly first contacted by Europeans such as Jacob Roggeveen in 1722 , universal museums like the British Museum were being established (I753). Nonetheless, it was not until I 868 that both parties crossed fates in a deeply colonialist relationship, when the crew of the English frigate H.M.S. Topaze landed in Rapa Nui and removed the moai (ancestor figure or statue) Hoa (friend) Hakananaia (lost, hidden or stolen) "with substantial aid of their shipmates, resident missionaries, colonials and nearly all members of a small Rapanui community" (Van Tilburg, 20I4, p. 383). Since then, I5I years ago, the Rapa Nui people as a community have not had the possibility of interacting with the Hoa Hakananai'a, whether in a spiritual or aesthetic sense.

As has been suggested (Van Tilburg, 2004; Pitts et al, 20I4; Cornejo González, 20I8), the moai Hoa Hakananai'a certainly is the most important object in Rapa Nui material culture and history, as it merges two spiritual approaches into one sacred representation. On the one hand, according to local historian Cristian Moreno Pakarati, the Hoa Hakananai'a "is a moai aringa ora (the living face of our ancestors), because of its shape and appearance it had a similar function to the rest of the moais" ' (Ma'u Henua TV, 2018) during the Ahu (ceremonial platform) Moai Phase (AD ıоoo-I600) (Van Tilburg, 2004, p. 19). Furthermore, this moai is particularly special as one of ten moais carved in basalt; its singularity becomes unique when we realize it is the only moai with its back inscribed with petroglyphs. On the other hand, precisely related to its back inscriptions, Van Tilburg stated that the carvings depict "two birdmen with human hands and feet, and frigate bird (Fregata minor, or makohe) heads". These motifs have been interpreted as the "typical depictions of the birdman (tangata manu) as a representation or incarnation of Makemake" (Rapa Nui creator god) (2004, p. 50). In consequence, once associated to the tangata manu (birdman cult), the moai gave continuity to its people's spirituality, becoming a central piece in Rapa Nui cultural development, at least until its physical removal in November I868.

I. All quotations from Rapa Nui people in this text have been translated from Spanish by the author. 
Regarding the context of its exodus, it is worth mentioning that the Hoa Hakananai'a was involved in poki manu (initiation or coming-of-age) rituals and the koro тапи (birdman ceremony or competition) until I867 (Van Tilburg, 2004; Ma'u Henua TV, 2018). This says that the moai was religiously active when it was removed from the island, hence one might assume that these rituals and ceremonies stopped being performed partly because of the physical absence of the Hoa Hakananai'a. At the same time, French missionaries encouraged the locals to abandon their ancestral beliefs in order to embrace Christianity, considering that Rapa Nui religious objects were pagan. In this period, the Rapa Nui population declined due to 'blackbirding' (enslaving), scarcity, famine and diseases brought through Western intrusion. As Van Tilburg pointed out in relation to the appropriation of sacred objects such as the moai Hoa Hakananai'a,

\author{
They were collected during a "liminal" time in Rapanui history, \\ when social bonds were tenuous, status was altered, order was \\ dictated by a colonial presence and the continuity of tradition was \\ uncertain (2014, p. 392).
}

99

Having established this setting, it can be said that the arrival of H.M.S. Topaze was not precisely seen as a colonial threat by the Rapa Nui community but as an opportunity, at least in part, for improving their already intricate life conditions. Accordingly, though pushed by necessity rather than diplomacy, one might understand why the Rapa Nui people helped the English to locate and transport the moai into the ship. However, despite apparent consensus about the meaning of the moai's name, it can be noted that this ambiguity or openness in the translation has no formal explanation from the British Museum. By contrast, local knowledge precisely attributes this vagueness to the historical context of the moai removal, as a manner of revealing that it was not a gift. Thus, the name Hoa Hakananai'a is commonly translated as lost, hidden or stolen friend. One could argue that, firstly, the moai is regarded as a friend, a close person or benevolent god. Secondly, consciously or not, by giving this name to the moai, the Rapa Nui community has implicitly enunciated or even denounced the very condition of being stolen to its most important sacred object. In other words, there was - and still is - a sense of mourning with the departure of the moai Hoa Hakananai'a, which has been expressed through oral tradition, in chants and even depicted in some tattoos (Ma’u Henua TV, 20r8).

\title{
Indigenous sacred objects in museums
}

Indigenous sacred objects are rarely sold or donated by their source communities when entering into a museum collection. More commonly, they are offered 
or bequeathed by a third party, who usually got the object in dubious circumstances associated to colonialism and/or hierarchical power relations. Hence, as Gaskell states, "When a sacred object enters a museum we generally think of it as being desacralized" (2008, p. 150), for instance, in the name of science, human understanding or aesthetic appreciation. According to Willis, "In all cases, whatever the historical cause, objects are divested of context, meaning and power", attributing to museums the connotation of places of amnesia rather than of memory (2015, p. 145). That is, identifying that the Universalist approach derived from the Enlightenment set of beliefs is basically the consecration of only one hegemonic perspective, which has historically neglected, omitted or forgotten the incorporation of others' voices in the interpretation of their own inheritance (Besterman, 2010; Curtis, 2012; Maranda, 2015). Consequently, it might be held that the universal museum not only detaches indigenous sacred objects from their spiritual meaning, but also hierarchically displays them in ways that perpetuate the idea of Western supremacy over the cultures these artworks represent. This latter issue is especially evident in some comparative religions' stances and world religions' museums, where, as noted by Orzech:

\begin{abstract}
Religions are treated as "Abrahamic" or "Asian", and as originating in the Near East (Judaism, Christianity, Islam), South Asia (Hinduism, Buddhism), and the Far East (Confucianism, Daoism, Shinto). The Remaining "little traditions" are grouped variously under the categories "tribal," "minority," or "primitive." Given limited time (or, in a museum, limited space), they are dealt with cursorily or not at all (2015, p. 135).
\end{abstract}

Similarly, in accordance with the aforementioned structure, since its incorporation in the British Museum collection and permanent exhibition, the moai Hoa Hakananai'a has been extremely succinctly interpreted and presented with bias (Cornejo González, 2018, p. 89), with neither an active contribution from the Rapa Nui community nor any historical, cultural, or political contextualization in order to appropriately value its relevance from a local or/ and global point of view. Obviously, words such as colonization, thief, abuse, imperialism are not revealed but, equally significant, there is no explanation for moai aringa ora, tangata manu ceremonies, or Makemake god. Moreover, the information provided does not explicitly state that Rapa Nui is a living Polynesian culture, whose relationship with ancestor/god representations is through a subject-to-subject basis. In other words, the Hoa Hakananai'a has been affected by "the museum's ability to dictate and influence how a particular cultural group is viewed through their displays", which is "at the root of the contestation of religious objects in museums," as suggested by Da Silva (2010, p. I7I). 


\section{The performative dimension of museums and sacred objects}

According to Macdonald, museums and exhibitions possess a performative dimension that can be understood as their physical capacity to perform, or simply "as a site for staging, spectatorship and enactment," for example, national identities (2012, p. 283). Yet, the concept of museums' performativity can also help us to envisage a better understanding of one of the most important issues of ethnology, anthropology of art and material culture: whether objects are able to achieve the status of personhood and how (Morgan, 20I2; Morphy, 20I2; Paine, 2013). To begin with, it seems pertinent to analyse the connections made by Knell (20I2, p. 325) and how this can be related to the case of the Hoa Hakananai'a:

The artwork, and all those individuals and institutions engaged in the production and reception of a work of art, might be understood ethnologically as forming a cultural grouping built around systems of belief which are produced and permeated by traditions and performances, which reify, consolidate and shape mutual values and understandings of the objects in their possession.

This ethnological metaphor reinforces and supports Brulon Soares' ideas of the museum religion and the museum as temple of a secular faith that systematically excludes other sets of beliefs within its realm. Correspondingly, as discussed in the musealization of the Hoa Hakananai'a, there is a historical absence of the individuals or institutions engaged in the production of the moai, namely Rapa Nui culture, in the current museological interpretation of the object. Therefore, one may state that the only traditions and performances carried out by this new cultural group - which has appropriated and reinterpreted the moai as an artwork - are those related to academia and cultural tourism. In this sense, although contemporary museology has promoted cross-cultural approaches founded on "diversity and mutual respect," it is undeniable that, in the case of the Hoa Hakananai'a, it has dominated the monotheist hegemony of museum religion: the aesthetic appreciation over the sacred conditions of religious objects (20I8, p. 46-47). Consequently, one could argue that, under a masquerade of neutrality or scientific objectivity (Reeve, 20I2, p. I29; Fleming, 20I2, p. 82), museums tend to deprive visitors of an understanding of sacred objects and the original performances that give them agency through their personhood condition.

In connection with this issue, Morgan establishes that "as a field of inquiry, material culture assumes that meaning does not inhere in things, but is activated by them," which means that the significance or value of a religious object relies on the ways the community, museum visitors in this case, interact with 
them (20I2, p. IоI). Likewise, in order to assess the value of objects upon this relational meaning-making conception, Morgan (20I2, p. IOI-IO2) states,

The value of an object will draw powerfully from its social career, that is, its circulation among people. As an object moves from one person to the next, from one social setting or one culture to the next, it acquires different values and associations, negotiating differences and carrying with it veneers of significance that will tell us much about what objects do [...] It is more productive to study the response to objects as they are displayed, exchanged, destroyed, and circulated in order to determine what they mean to people [...] Meaning is not only abstract and discursive, but embodied, felt, interactive and cumulative.

Interestingly, this assertion moves us into the field of actions, embodiment and proprioception, which can lead us to approach museology from the perspective of what is happening in museums instead of what is inside a museum. However, even though it seems to be an illuminating claim, the agency of sacred objects and their visitors' relational meaning-making have been controversial depending on point of view within the discipline and even within the same field of study. For instance, regarding the agency of things, Gell (20I2, p. 340-34I) states that,

The concept of agency I employ here is exclusively relational: for any agent, there is a patient, and conversely [...] the concept of the 'patient' is not, therefore a simple one, in that being a 'patient' may be a form of (derivative) agency.

9

As a result, one might agree that Gell is not saying that objects can actually think or act, but their agency depends on the interaction with a human-person in a derivative relation. Conversely, in opposition to Gell's proposition, Morphy (2012, p. 345) replies,

If an anthropologist is interested in the phenomenology of religious experience, then how people come to believe in the magical properties or spiritual power, or affect of a particular object becomes a central question [...] I see the 'how' question as one of the most important questions in the anthropology of art and Gell does not really attempt to answer it. 
By showing this controversy, I am not trying to refute Morphy's analysis of Gell's agency of "religious things," as I am not an anthropologist and my claims are not based on that particular disciplinary field. I am trying to open up discussion about museums and the ways in which they can understand, interpret, and present their collections, especially with indigenous sacred objects. For this purpose, it can be more beneficial to embrace "the notion that not all persons are human persons - some may be statue-persons, or tree-persons, or rock-persons"; however, concerning what it has been called "new animism," Paine (2013, p. 9) suggests,

An object-person is only 'alive' when interacting with a human-person - the act of relating is what does the animating. This 'relationality' means that every encounter is different, and any attempt to define the 'true nature' of the non-human person involved is doomed. It also gives added emphasis to the importance of performance, another area of study that has made big contributions to material cultural studies and especially to religious studies.

In summary, I would like to refer to performativity and embodiment as resulting concepts from this partial exploration of the agency of things. Performativity has been crucial for gender studies in recent decades; nonetheless, it has been also helpful for other humanities. Here it is being incorporated for understanding the agency of indigenous sacred objects in a social and relational manner, as Butler points out (I999, p. I25),

The social performative is a crucial part not only of subject formation, but of the ongoing political contestation and reformulation of the subject as well. In this sense, the performative is not only a ritual practice: it is one of the influential rituals by which subjects are formed and reformulated.

Therefore, when connecting with the Hoa Hakananai'a and its exhibition in the British Museum, one could say that (from now) his identity has not only been conformed through his lifetime and contact with different people and cultures (inside and outside the island), but it is being continuously reformulated by his relational performance with human-persons. Thus, it can be argued that, as with the Rapa Nui culture and people, the Hoa Hakananai'a is also alive. As such, he is able to interact in a full personhood mode by way of his/our mind and body. However, as Curtis (2012, p. 75) observed in the Declaration on the importance and value of universal museums, institutions such as the Bri- 
tish Museum proclaim an "emphasis on objects as art," which implies that its agency is denied when an object is only regarded for visual appreciation and not multisensory experience by the interaction of our bodies. Interestingly, as noted by Shusterman (2006, p. I6), the importance of the body in the aesthetic experience "is sadly neglected in contemporary philosophy, though it has often been crucial to the philosophical life in both ancient and non-Western cultures." Accordingly, being conscious of performativity's potential might also help $2 \mathrm{I}^{\mathrm{st}}$ century museums in decolonizing their practices through the integration of divergent, non-Western, ways of interpreting their collections. Indeed, by doing so, museums could promote participation, diversity and constructive connections with visitors and source communities alike, as contemporary museology has insistently urged for (Sandell \& Nightingale, 20I2). Hence, it seems to be necessary to ask why is this not happening? Where is the focus and what is the purpose of the universal museum today?

\title{
Hoa Hakananai'a in contemporary museology
}

As it has been observed, museums have experienced several changes through their history; although some changes can be understood as universal phenomena such as the Enlightenment and globalisation, most of them are related to particular contexts of cultural, socio-economic and political change. In this regard, Brown \& Mairesse (2018, p. 526) suggest,

\begin{abstract}
We are working in a fractured, unequal world where the concept of "museum" differs significantly, sometimes completely, from one institution to another, from one country to another, one culture to another, and one language to another.
\end{abstract}

In consequence, at present there seems to be no need to establish (or keep) a universal and homogeneous structure for museums that provides global solutions with a sort of magic formula (Brulon Soares, 2018). Correspondingly, it is also hard to maintain the universal museum's narrative with its Eurocentric, scientific and rational perspective as the exclusive method for understanding collections, particularly religious objects from indigenous cultures. Therefore, it would be useful to contextualise the case in order to appropriately grasp it. The Hoa Hakananai'a, while physically situated in London, has his original land and cultural community I3,640.92 km away, whereas Rapa Nui, which has the constitutional status of a Chilean special territory, is $3,671.77 \mathrm{~km}$ from the mainland. In this regard, the moai and Rapa Nui though culturally belonging to Polynesia, are administratively South Americans. Hence, if universal museums were open to hearing voices from local or source communities in the interpretation of sacred objects, such as the Hoa Hakananai'a, the British Museum could easily look at the experiences of museums in Oceania and Latin 
America. Why can this be relevant? According to Brown \& Mairesse, one significant contribution to challenging the Western universal museum approach was developed in the Round Table on the role of museums in relation to the social and economic needs of modern day Latin America held in Santiago, Chile, in 1972. As a result, the final declaration outlined the conception of the integral museum, which emphasizes "the social role of museum" that "can be understood as a form of resistance"; then "these anti-elitist ideas and practices challenged existing structures in society, and worked towards cultural decolonization" (2018, p.527-529).

In addition, it can be suggested that this seminal declaration has triggered museums' focus to move onto communities rather than collections, which implies the introduction of more democratic ways of participation and the inclusion of others' voices. Unsurprisingly, most of the issues related to the exhibit of the Hoa Hakananai'a in the British Museum have been addressed by this 'Latin New Museology'. Nonetheless, these ideas have been echoed abroad through radical turns in contemporary museum approaches. For the Hoa Hakananai'a analysis, the most important is the educational turn that precisely confronts the division of mind-body in the aesthetic appreciation of sacred objects discussed above. As Hooper-Greenhill asserts,

The emotions play a strong role in learning, and the separation between cognitive and affective learning, and between mind and body as resources for interpretation, has been shown to be artificial (2007, p. 372).

Consequently, what comes into play here is not only the incorporation of the physical body and the senses, but also the inclusion of emotions and affectivity in the learning and meaning-making processes of visitors, whose cognition is also related with their own identities. As claimed by Hooper-Greenhill, "learning in museums is never just about learning about the collections, it is also about the shaping of views about the self" (2007, p. 375). This educational turn, as well as the emphasis on the social role of museums, essentially reveals a change to a paradigm of caring; this means taking care not only of collections, but specifically of the public who configure new meanings to sacred objects and actually bring them to life through derivative agency. Hence, we are witnessing a crucial revolution in museum conception, which is from a scientific, patriarchal and white perspective to a more feminist standpoint structured on affect and interculturality (Golding, 2013).

Inevitably, everything discussed so far is linked to a bigger claim regarding structural changes in society, thus in museums. As Hooper-Greenhill states in relation to $2 \mathrm{I}^{\text {st }}$ century societies, now it is "no longer necessary to be white, educated, able-body, metropolitan, Western and male in order to be regarded 
as fully human" (2007, p. 372). However, taking into account the questionable acquisition of the object and the lack of source-community participation in the moai Hoa Hakananai'a interpretation, it can be argued that, in order to find solutions to this problem, we still have to wait for a complete commitment of the human rights-based approach in universal museums. In the meantime, this approach has proven to be successful in a number of opportunities that range from community partnership to the repatriation of sacred objects and human remains in countries such as New Zealand, Australia, and Canada (see Hakiwai, 2004; Simpson, 2007; Tapsell, 2012; Tapsell, 2014; Maranda, 2015). However, the Rapa Nui community can hardly replicate these interesting examples as, in all of them, the source community and museum share the same territory and the same legal framework, which is not the situation of Hoa Hakananai'a. Subsequently, the Rapa Nui culture is not only being considered as less valuable than more "traditional" religions and cultures, but is also at a disadvantage as it does not have an embodied local community that can represent and defend its interest in museum governance as a partner community. Similarly, as Rapa Nui culture is not a state-nation on its own, it cannot stand up for its cultural rights in a state-to-state discussion (Meskell, 20I0; Reeve, 20I2; Maranda, 2015).

For these reasons, it can be argued that, for now, the Rapa Nui community has little possibility of establishing a productive partnership with the British Museum. In fact, after being refused as an indigenous community and valid counterpart in their first attempt for the repatriation of the Hoa Hakananai'a, the Chilean state took part in the demand and is currently sponsoring the dialogue between the Rapa Nui and the museum. However, conscious of the British Museum's standpoint, Moreno Pakarati has stated,

Their argument has always been that of protection [...] our argument has to be what this moai represents for us, for the Rapa Nui of today and what represented for all our ancestors. The moai cannot fulfill its function at $13,600 \mathrm{~km}$ distance, in that room. Where, very few people in our community had the chance to see it, where very few people in our community had the opportunity to reconnect with that spirit, with that person (Ma'u Henua TV, 2018).

In conclusion, it can be considered that the claim for the repatriation of the Hoa Hakananai'a is partly due to the "universal museum" unwillingness to incorporate its source community in the interpretation and presentation of the object. According to Tapsell, this attitude can only derive from more repatriation demands from native cultures (2012, p. 578). At least now, the Rapa Nui people do not have to deal with the same problems of early colonialism and they can focus on the search for their "legitimacy" and "cultural integrity and ethnic realism", which "is a search that challenges the museum orthodoxy 
and raises questions about how we define what a museum is" (Hakiwai, 2004, p. I6I). This leads us to the main question of this paper: what is the role of museums in contemporary societies?

It has been argued that the incorporation of performativity in museums might not only provide benefits for source communities and visitors, in the ways sacred objects are approached, but also can be helpful for understanding museums as subjects or living beings. As such, they can also be transformed and reformulated into the institutions contemporary society demands. In this regard, it seems to be clear that today's museum must be a place of consensus and lead by example of ethical behaviour. Certainly, museums as a site for enactment are the ideal stage for performing the ritual practice of harmonic partnership and social cohesion; hence, when talking about universal museums, there should be a sense of responsibility of being duty-bearers of the communities' human rights present in their collections. Thus, as expressed in their declaration, if universal museums consider repatriation as a "disservice to all visitors," then they must be worried to establish respectful collaboration and partnership in the interpretation of indigenous sacred objects. In the case of the current Hoa Hakananai'a exhibit and visitors' usage of the moai, mainly for taking photographs of an exotic object, it does not matter if it is the original or not. Hence, why not try the suggested replacement of the object with a replica made by contemporary Rapa Nui carvers? Otherwise, introducing Rapa Nui cultural voices in the interpretation and display of the Hoa Hakananai'a does not appear so unattainable. This is a great opportunity to show how things must be done ethically in museums of the $2 \mathrm{I}^{\mathrm{st}}$ century. Finally, one might expect that the role of museums in contemporary societies is to be a role model for the global community.

\section{References}

Besterman, T. (2010). Museum ethics. In S. Macdonald (Ed.), A companion to museum studies. (pp. 431-44I). Chichester, United Kingdom: John Wiley \& Sons.

Brown, K., \& Mairesse, F. (20I8). The definition of the museum through its social role. Curator: The Museum Journal, 61(4), 525-539.

Brulon Soares, B. (2018) Every museum has a God, or God is in every museum? In F. Mairesse (Ed.), Museology and the Sacred: Materials for a discussion. (pp. 44-48). Paris, France: ICOFOM - ICOM.

Butler, J. (I999). Performativity's social magic. In R. Shusterman (Ed.), Bourdieu: a critical reader. (pp. II3-I28). Oxford, United Kingdom: Blackwell Publishers. 
Cornejo González, M. (2018). Moái Hoa Hakananai’a, from Orongo to the British Museum: Reflections upon religious art exhibitions in museums. In F. Mairesse (Ed.), Museology and the Sacred: Materials for a discussion. (pp. 87-91). Paris, France: ICOFOM.

Curtis, N. G. (20I2). Universal Museums, Museum Objects and Repatriation. In B. M. Carbonell (Ed.), Museum studies: An anthology of contexts. (pp. 73-8I) Chicester, United Kingdom: John Wiley \& Sons.

Da Silva, N. (20ro). Religious displays: an observational study with a focus on the Horniman museum. Material Religion, 6(2), I66-I9I.

Delbourgo, J. (2007). Slavery in the cabinet of curiosities: Hans Sloane's Atlantic world. The British Museum. Retrieved from https://www.britishmuseum. org/PDF/Delbourgo\%2oessay.pdf

Fleming, D. (2012). Museums for social justice: managing organisational change. In R. Sandell \& E. Nightingale (Eds.), Museums, equality and social justice. (pp. 72-83). London, United Kingdom: Routledge.

Gaskell, I. (2008). Sacred to profane and back again. In A. McClellan (Ed.), Art and its publics: Museum studies at the millennium. (pp. I49-I64). Oxford, United Kingdom: John Wiley \& Sons.

Gell, A. (2012). 'Things' as social agents. In S. H. Dudley (Ed.), Museum objects: Experiencing the properties of things. (pp. 336-343). London, United Kingdom: Routledge.

Golding, V. (2013). Museums, poetics and affect. Feminist Review, 104(1), 80-99. Retrieved from http://www.jstor.org/stable/24571951

Hakiwai, A. T. (2004). The search for legitimacy: Museums in Aotearoa, New Zealand-a Maori viewpoint. In G. Corsane (Ed.), Heritage, Museums and Galleries: An Introductory Reader. (pp. 283-294). London, United Kingdom: Routledge.

Hall, S. (I997). The Spectacle of the «Other». In S. Hall (Ed.), Representation: Cultural representations and signifying practices. (pp. 225-279). Thousand Oaks, United States: Sage/Open University Press.

Hooper-Greenhill, E. (2007). Education, postmodernity and the museum. In S. J. Knell, S. MacLeod \& S. Watson (Eds.), Museum revolutions: How museums change and are changed. (pp. 367-377). London, United Kingdom: Routledge.

Knell, S. J. (2012). The intangibility of things. In S. H. Dudley (Ed.). Museum objects: Experiencing the properties of things. (pp. 324-335). London, United Kingdom: Routledge. 
Macdonald, S. J. (2012). Museums, national, postnational and transcultural identities. In B. M. Carbonell (Ed.), Museum studies: An anthology of contexts. (pp. 273-286). Chichester, United Kingdom: John Wiley \& Sons.

Maranda, L. (2015). Museum Ethics in the 21 ${ }^{\text {st }}$ Century: Museum Ethics Transforming into Another Dimension. ICOFOM Study Series, 43b, I5I-165.

Ma’u Henua TV. (20I8, December 7). TE HAU HA'A TUPUNA, capítulo I. [Video file]. Retrieved from https://www.youtube.com/watch?v=nLP8st2PlUo

Meskell, L. (20I0). Human rights and heritage ethics. Anthropological Quarterly, 83(4), 839-859.

Morgan, D. (2012). The materiality of cultural construction. In S. H. Dudley (Ed.), Museum objects: Experiencing the properties of things. (pp. IOI-IO2) London, United Kingdom: Routledge.

Morphy, H. (20I2). Art as a mode of action: some problems with Gell's art and agency. In S. H. Dudley (Ed.), Museum objects: Experiencing the properties of things. (pp. 344-362). London, United Kingdom: Routledge.

Orzech, C. (2015). World religions museums: dialogue, domestication, and the sacred gaze. In B. M. Sullivan (Ed.), Sacred Objects in Secular Spaces: Exhibiting Asian Religions in Museums. (pp. I33-I44). London, United Kingdom: Bloomsbury Publishing.

Paine, C. (2013). Religious objects in museums: Private lives and public duties. London, United Kingdom: Bloomsbury Publishing.

Peiser, B. (2005). From genocide to ecocide: the rape of Rapa Nui. Energy \& Environment, I6(3-4), 513-539.

Pitts, M., Miles, J., Pagi, H., \& Earl, G. (20I4). Hoa Hakananai'a: a new study of an Easter Island Statue in the British Museum. The Antiquaries Journal, 94, 291-32I.

Reeve, J. (2012). A question of faith: The museum as spiritual or secular space. In R. Sandell \& E. Nightingale (Eds.), Museums, equality and social justice. (pp. I25-I4I). London, United Kingdom: Routledge.

Sandell, R. (2012). Museums and the human rights frame. In R. Sandell \& E. Nightingale (Eds.), Museums, equality and social justice. (pp. 195-215). London, United Kingdom: Routledge.

Seelenfreund, A., \& Mardones, A. (2018). El doble descubrimiento en Rapa Nui: Una mirada desde los textiles. Antropologías del Sur, 5(Io), I5-36.

Shusterman, R. (2006). Thinking through the body, educating for the humanities: A plea for somaesthetics. Journal of Aesthetic Education, 4O(I), I-2I. 
Simpson, M. G. (2007). Charting the boundaries: indigenous models and parallel practices in the development of the post-museum. In Knell, S. J., MacLeod, S., \& Watson, S. (Eds.). Museum revolutions: How museums change and are changed. (pp. 26I-275). London, United Kingdom: Routledge.

Tapsell, P. (20I2). Partnership in Museums: A Tribal Maori Response to Repatriation. In B. M. Carbonell (Ed.), Museum studies: An anthology of contexts. (pp. 575-579) Chicester, United Kingdom: John Wiley \& Sons.

Tapsell, P. (2014). Ko Tawa: Where are the glass cabinets? In R. Silverman (Ed.), Museum as process: translating local and global knowledges. (pp. 262-278). London, United Kingdom: Routledge.

Tcherkézoff, S. (2008). First contacts in Polynesia: The Samoan Case (I722-1848) Western Misunderstandings about Sexuality and Divinity. Canberra, Australia: Anu Press

Van Tilburg, J. (2004). Hoa Hakananai'a. London, United Kingdom: British Museum Publications Limited.

Van Tilburg, J. A. (2014). Lost and found: Hoa Hakananai'a and the Orongo «Doorpost». The Journal of the Polynesian Society, I23(4), 383-397.

Willis, M. (2015). Detritus to Treasure: Memory, Metonymy, and the Museum. In B. M. Sullivan (Ed.). Sacred Objects in Secular Spaces: Exhibiting Asian Religions in Museums. (pp. I45-152). London, United Kingdom: Bloomsbury Publishing.

Young, F. W. (20I2). 'I Hē Koe? Placing Rapa Nui. The Contemporary Pacific, $24(\mathrm{I}), \mathrm{I}-30$. 